\title{
Karriertervezés és kompetenciák vizsgálata egyetemisták körében
}

\author{
SZONDI RÉKA ${ }^{1}$
}

\begin{abstract}
ABSZTRAKT
A karriertervezést nem lehet elég korán kezdeni. A karrierút melletti elhatározást komoly döntések és célok elözik meg. Számos kutatás foglalkozik a fiatal felnöttek önismeretének és karrierterveinek kapcsolatával a munkakeresés tükrében. Az egyetemi hallgatók ritkán rendelkeznek megfelelö önismerettel. A munkaerö-piacon napjainkban a végzettség mellett egyre nagyobb jelentöséggel bírnak a kompetenciák. A sikeres elhelyezkedéshez, minöségi munka megtalálásához elengedhetetlen bizonyos kommunikációs, beilleszkedési, stratégiai készségek megléte. A Debreceni Egyetem lehetöséget nyújt a hallgatói számára többféle egyéni álláskeresési támogatás vagy tanácsadás és pályaorientációs szolgáltatás igénybevételére. A kutatásban részt vevő hallgatók a szolgáltatások és kompetenciák fontosságát értékelték a későbbi elhelyezkedés megkönnyítését illetően. Az elérhető szolgáltatások ismerete és a munkaerôpiac által elvárt, illetve meglévő kompetenciák közötti összhang segíti a hallgatókat a diplomaszerzést követő álláskeresésben. A vizsgálathoz tartozó kérdöívet a Debreceni Egyetem hallgatói töltötték ki, az adatok feldolgozása IBM SPSS Statistics programmal történt.
\end{abstract}

KULCSSZAVAK: hallgató, karrier, karriertervezés, kompetencia, munkaerőpiac

\section{ABSTRACT}

\section{An analysis of the career planning competencies of students} at the University of Debrecen

Planning a career cannot be started soon enough. The determination of following a career path preceded by significant decisions and aims. Several pieces of research are dedicated to the affiliation of young adults self-awareness and career paths in terms of seeking work. Universitystudents rarely have the appropriate amountofself-knowledge. Nowadays in the labour market beside the qualification, competencies are growing kola.

${ }^{1}$ PhD hallgató, Debreceni Egyetem, Ihrig Károly Gazdálkodás- és Szervezéstudományok Doktori Is- 


\section{TEMATIKUS TANULMÁNYOK - A munkaerőpiac gazdasági-társadalmi kérdései}

in importance. It is crucial to have certain communication, integration and strategic skills to successfully find a quality job. The University of Debrecen provides a wide variety of available services regarding individual job search support or consultation and the commitment of a career path. The surveyed university students valued the importance of these services and competencies related to improving the finding of a job after graduation. The conformity between the knowledge of the available services and the required and existing skills could be helpful in the labour market after getting the university degree. The questionnaire was filled out by students from the University of Debrecen and valued by the IBM SPSS Statistics programme.

KEYWORDS: student, career, career planning, competency, labour market

\section{Bevezetés}

A karrierút megtervezésével érdemes minél előbb foglalkozni. Karrierperiódusok függvényében való csoportosíthatóság szempontjából, a kutatásban megkérdezettek a kezdeti karrier szakaszába tehetők. Ebben a szakaszban az egyetemi képzés megválasztásával az elhelyezkedésük egyik lehetséges területét már eldöntötték. A hallgatók sokszor azonban még nem rendelkeznek megfelelő önismerettel, ami kulcsfontosságú a munkaerőpiacra történő belépéshez, ezért fokozottan szükség van a karriertervezésben nyújtott segítségre. A tanulmányban a karrier előremozdításához szükséges kompetenciákat értékeltek a kitöltők, aszerint, hogy számukra milyen mértékben fontosak. A kompetenciák felmérése segít az önismeret mélyítésében, az így megszerzett tudás pedig a karrierorientációban, és a tervezésben is segítséget nyújthat. A második blokkban különböző szolgáltatások kerültek, melyek igénybevételének, lényegességének pontozására vonatkozott instrukció. A szolgáltatások között szerepel többek közt, a motivációs levél és az önéletrajz elkészítésében nyújtott támogatás, álláskeresési technikák ismerete, interjúkra való felkészítés. A jövőbeli karrierút melletti elköteleződés nem egyszerű feladat, de a munkaerőpiacon előnyt jelent, ha tisztában van a munkát kereső a saját igényeivel és a legtöbb elérhető információval. A diploma versenyképességét növeli, ha az álláskeresési időszak lerövidül, melyben kiemelt jelentőségủ a frissen végzett tájékozottsága a számára rendelkezésre álló lehetőségekről. Az önismeret megléte hozzájárul a megfelelő állásajánlatokra történő jelentkezésekhez, továbbá a későbbi munkahely értékeinek és a szervezeti kultúrának az elfogadásához, az ahhoz történő illeszkedéshez. 


\section{TEMATIKUS TANULMÁNYOK - A munkaerőpiac gazdasági-társadalmi kérdései}

\section{Karrier, kompetenciák}

A karriert a köznyelvben gyakran azonosítjuk a vezetői kinevezésekkel. Ám a karrier nemcsak vezetői, hanem szakmai is lehet. Míg az első esetében egy vertikális, hierarchikus karrierről beszélhetünk, addig az utóbbi esetében az előmenetel a szakmai tudáson és alkotási képességen alapul. Az egyén életpályája során egyre nagyobb szakmai kihívásoknak felel meg és a kivívott elismerés is egyre nő. A szakmai (horizontális) karrier modelljében az egyén rendelkezik egy olyan szakmai tudással, amellyel mások nem, és erre a tudásra van szüksége a szervezetnek, ezért képes előrelépni a szervezeten belül. A szakmai karrier lényege tehát az, hogy egy alacsonyabb kompetencia- és tudásigényű munkakörből egy magasabb értékű munkakörbe lép át az egyén (Nemeskéri 2008).

Powell (1995) tanulmányában, a karriertervezés négy alappillérjét különbözteti meg. Az első pillérbe az önértékelés tartozik, a másodikba a lehetséges karrierút feltérképezése, a harmadik pillér a célok meghatározása, a negyedik pedig a cselekvés elkezdése, tehát az elhelyezkedés, vagy továbbtanulás. A pillérek egymásutániságában a döntés és a tudatosság is fontos szerepet játszik. A karriertervezés kapcsán lényeges szempont a foglalkoztathatóság vizsgálata is. Watts (2006) három különálló csoportba osztotta, ezek az azonnali foglalkoztatás, az azonnali foglalkoztathatóság, és a fenntartható foglalkoztathatóság. A csoportok jellemzésénél, az azonnali foglalkoztatás alatt a hat hónappal a végzettség megszerzése után állást találókra gondol a szerző. Az azonnali foglalkoztathatóságnál pedig előtérbe kerül, hogy a végzett hallgató tulajdonában állnak-e azok a képességek és kompetenciák, melyeket egyből képes alkalmazni egy állás betöltésekor. A fenntartható foglalkoztathatóság leírja, hogy nem csupán az első állás megszerzése a fontos a diploma megszerzését követően, hanem az állás megtartása is (Csehné 2016). Több Y generációval kapcsolatos kutatásban (Koncz 2013, Juhász - Terjék 2013) megjelenik, hogy a fiatalok elvárásai közé tartozik a magas jövedelem, a rugalmas munkaidő, a folyamatos lehetőség a fejlődésre, előmenetelre. Ha elvárásaik nem kapnak teret, gyakran váltanak munkahelyet. A munkakeresés során nagy hangsúly van a képességeken és készségeken.

A hallgatók számára fontos a megfelelő karriertudatosság. A karriertudatosság megfogalmazható egyfajta képességként, melynek segítségével megítélhető, hogy az egyén milyen mértékben látja reálisan saját hosszú távú foglalkoztathatósági és fejlődési feltételeit. Akik karriertudatosabbak, pontosabban fel tudják mérni, miben kell még tudásra, ismétlésre szert tenniük, hogy az általuk választott területen eredményesebben tudjanak elhelyezkedni és teljesítményüket fenntartani, növelni (Takács et al. 2017).

A kutatás kapcsán előtérbe kerül a kompetencia értelmezése is. A kompetencia fogalmának több megközelítése ismeretes. Maga a szó latin eredetű, és alkalmasságot, ügyességet jelent. A köznyelv szintjén rokonértelműként használják a hatáskörrel, illetékességgel, valamint a hozzáértéssel. Érdemes megnézni néhány kom- 


\section{TEMATIKUS TANULMÁNYOK - A munkaerőpiac gazdasági-társadalmi kérdései}

petenciára adott definíciót, a teljesség igénye nélkül. Armstrong (2012) alapján a kompetencia nem más, mint az egyén karakterének a részegysége, ami hosszú távon meghatározza a hatékony teljesítményt. Más megközelítés szerint (Nemeskéri 2008), a kompetencia azonos a tudással, és azt is jelenti, hogy az adott személy képes valamit véghezvinni, ami a szervezet számára jelent értéket. Spencer és Spencer (2016) megfogalmazásában, a kompetenciák a személy alapvető jellemzői és kapcsolatban vannak a teljesítménnyel. A kompetenciák megjelennek a cselekvéseinkben és tevékenységeinkben, melyek így válnak értékelhetővé és a teljesítmény szintjén mérhetővé is. A részjellemzők tekintetében tehát a kompetenciák személyhez kötöttek. Összetevőiket nézve megfogalmazhatók, mint olyan jellemzők összessége, amelyek megkülönböztetik a többi embertől, kiemelik az átlagból és kiválóként jellemzik az egyént (Nemeskéri - Pataki 2008).

Mind az egyéni, mind a szervezeti kompetenciák kötődnek a szervezethez. A szervezeti kompetencia építkezik az egyéniből, így a szervezeti kompetenciákhoz kötődik az egyéni és kollektív képesség, a szaktudás és a kapacitások összegének rendszere (Veresné 2011).

Napjainkban elképzelhetetlen a munkaerőpiacon versenyképesnek lenni, ha az egyén nem képes a megújulásra, a folyamatos tanulásra és nem rendelkezik megfelelő önismerettel. A munkaerőpiac globalizációja okozta változásoknak talán legfontosabb oktatáspolitikai következménye, hogy a kizárólag egy szakterületre fókuszáló szaktudás helyett, könnyen adaptálható és megszerezhető kompetenciákra, képességekre mutatkozik igény (F. Silye 2004).

Összegezve a kompetenciákról leírtakat, a meglétük lehetővé teszi a megtanultak eredményes és értékes felhasználását, az alkalmazkodást, önmagunk fejlesztését és a minket körülvevő környezet innovációját (Henczi - Zöllei 2007).

Az álláshirdetéseket vizsgálva, a munkáltatók mindig követelik valamely kompetencia meglétét az állás betöltéséhez. Ám a hirdetésekben gyakran összekeverik a készségeket, képességeket, ismereteket, a személyes tulajdonságokat, adottságokat, a beállítódást. Így gyakran sorolják kompetenciákhoz a lojalitást, a jó kommunikációs készséget, informatikai és nyelvi ismeretet, megbízhatóságot, vevőorientáltságot is. Ezek gyakran egy részterületet fednek le, nem esnek egybe a kompetenciával (Gaál et al. 2013).

A hallgatóknak ezért is kiemelten lényeges, hogy tudatosan tervezzék meg a karrierútjukat, legyenek tisztában a céljaikkal és az azokhoz vezető lépésekkel. Ha az egyén fel tudja vázolni karrierjének lépcsőit, könnyen átláthatja azt is, milyen kompetenciák válnak majd számára lényegessé, és miben szükséges fejlődnie, esetleg milyen hiányzó képességeket érdemes elsajátítani. A tudatosan megtervezett karrier gyakran párosul a sikerességgel, eredményességgel. Azonban az egyetemekre bekerült hallgatók még ritkán rendelkeznek konkrét célokkal és tervvel a jövőjüket tekintve. A folyamat segítségére szolgálnak az egyetem által nyújtott szolgáltatások, 


\section{TEMATIKUS TANULMÁNYOK - A munkaerőpiac gazdasági-társadalmi kérdései}

amelyek a legkorábbi szakaszban a szakmai gyakorlati helyek kiválasztásánál már többlettudást adnak. A későbbiek folyamán az álláskeresés előtt álló végzős hallgatók profitálhatnak a munkaerőpiaci ismeretek megszerzéséből, a próbainterjúkból, önéletrajz megírásában nyújtott segítségből stb.

\section{Anyag és módszertan}

A kutatás vizsgálata során primer és szekunder adatgyújtési módszereket és adatelemzést alkalmaztam. A primer adatgyűjtéshez készített kérdőív papír alapon került kitöltetésre 2017 szeptemberében. Összesen 266 válasz került feldolgozásra. A vizsgálat során a Debreceni Egyetem Gazdaságtudományi Karán lévő, eltérő képzéseken, szakon tanuló hallgatók vettek részt. A kutatás nem reprezentatív jellegü, az eredmények csak a kérdőívet kitöltő sokaságra vonatkozik.

A kérdőív az azonosító adatokból és további két szekcióból áll. Az elsőben a hallgatók a felsorolt kompetenciák fontosságát értékelték az alapján, hogy milyen fontosnak találják a karrierjük előremozdításában. A blokk összeállításakor a HencziZöllei- (2007) féle kompetenciaszótárt vettem kiinduló pontnak. A második blokk a karriertervezéssel és annak támogatásával összefüggő szolgáltatásokat tartalmazott, amelyet a Debreceni Egyetem Hallgatói Karrierközpont pályaorientációs munkatársával került összeállításra. A hallgatók értékelték az egyes szolgáltatásokat aszerint, hogy melyeket vennék inkább igénybe a karriertervezésük támogatására.

Az állítások értékelésére a hallgatóknak egy hatfokozatú Likert-skála állt a rendelkezésükre, amelyek szélső értékei az egyáltalán nem ért egyet (1) és a teljes mértékben egyet ért (6) az adott állítással. Az eredmények vizsgálatához az IBM SPSS Statistics 23.0 adatelemző programot alkalmaztam. Az adatok értékeléséhez számtani közepet, szórást, relatív szórást, Khi-négyzet próbát és Pearson-féle korrelációszámítást alkalmaztam.

\section{Eredmények}

A kutatás eredményeinek ismertetése a csoportképző kérdésekből, ezt követően a kérdőív szekcióinak leíró statisztikájából, legfőbb korrelációs értékeiből és Khi-négyzet próbáiból áll. A kérdőív kitöltőinek demográfiai jellemzőit, a kérdőívben szereplő hat csoportképző kérdés összegzését az 1. táblázat szemlélteti. 
www. metszetek.unideb.hu

\section{TEMATIKUS TANULMÁNYOK - A munkaerőpiac gazdasági-társadalmi kérdései}

1. táblázat. A sokaság demográfiai jellemző

\begin{tabular}{|c|c|}
\hline Demográfiai tényezők & $\begin{array}{c}\text { Teljes minta }(n=266) \\
\%\end{array}$ \\
\hline \multicolumn{2}{|l|}{ Nem } \\
\hline Nő & 63,2 \\
\hline Férfi & 36,8 \\
\hline \multicolumn{2}{|l|}{ Életkor (év) } \\
\hline $18-21$ & 75,6 \\
\hline $22-25$ & 22,9 \\
\hline $26-29$ & 1,1 \\
\hline 29 felett & 0,4 \\
\hline \multicolumn{2}{|l|}{ Állandó lakhely } \\
\hline Főváros & 0,4 \\
\hline Megyeszékhely & 35,0 \\
\hline Város & 43,2 \\
\hline Falu vagy kisebb település & 21,4 \\
\hline \multicolumn{2}{|l|}{ Egyetemi szak } \\
\hline Gazdálkodás és menedzsment & 26,7 \\
\hline Kereskedelem és marketing & 17,7 \\
\hline Turizmus és vendéglátás & 15,0 \\
\hline Sportszervező & 14,3 \\
\hline Pénzügy és számvitel & 9,4 \\
\hline Nemzetközi gazdálkodás & 8,6 \\
\hline Emberi erőforrás tanácsadó & 4,9 \\
\hline Gazdasági agrármérnök & 1,9 \\
\hline Vidékfejlesztési agrármérnök & 1,5 \\
\hline \multicolumn{2}{|l|}{ Képzési szint } \\
\hline Felsőoktatási szakképzés & 29,7 \\
\hline BA/BSc 1-2. évfolyam & 48,9 \\
\hline BA/BSc 3-4. évfolyam & 12,8 \\
\hline $\mathrm{MA} / \mathrm{MSc}$ & 8,6 \\
\hline
\end{tabular}

Forrás: Saját szerkesztés, 2017 


\section{TEMATIKUS TANULMÁNYOK - A munkaerőpiac gazdasági-társadalmi kérdései}

A kérdőívet kitöltők 63,2\%-a nő, életkoruk alapján a sokaság háromnegyede a 18-21 év közötti csoportba esik. Lakóhely alapján a megyeszékhely és a város kategóriába tartozik a többség. A vizsgálat során kilenc egyetemi szak hallgatói lettek felmérve. Legnagyobb arányban a Gazdálkodás és menedzsment, illetve a Kereskedelem és marketing szakos hallgatók vannak jelen a sokaságban. A kitöltők közel fele BA/BSc 1-2. évfolyamon tanul, továbbá a megkérdezettek közel harmada Felsőoktatási szakképzés keretein belül végzi tanulmányait a Debreceni Egyetemen.

\subsection{A KOMPETENCIA LISTA LEÍRÓ STATISZTIKÁJA, KORRELÁCIÓ ÉS KHI-NÉGYZET PRÓBÁK}

A szekcióban összesen 21 kompetenciát értékeltek a hallgatók. A kompetenciák felsorolásában megjelent többek között, a rugalmasság, kreativitás, önálló döntéshozatal, az idegen nyelvek ismerete, a stratégiai előrelátás, vezetési készségek és az érzelmi intelligencia is. A 2. táblázat szemlélteti a legjelentősebb homogén és heterogén válaszokat, melyek kiemelésre érdemesek.

2. táblázat. Kompetenciák értékelése

\begin{tabular}{|l|c|c|c|}
\hline & $\begin{array}{c}\text { Átlag } \\
\text { (pontszám) }\end{array}$ & Szórás értéke & $\begin{array}{c}\text { Relatív szórás } \\
\text { (\%) }\end{array}$ \\
\hline Kommunikáció, tárgyalóképesség & 5,48 & 0,72 & 13,25 \\
\hline Jó beszédkészség & 5,46 & 0,70 & 12,81 \\
\hline Belső motiváció & 5,33 & 0,82 & 15,40 \\
\hline Etikus hozzáállás & 4,20 & 1,12 & 26,64 \\
\hline Kritikus szemléletmód & 3,73 & 1,07 & 28,71 \\
\hline Bizonytalanság toleranciája & 3,57 & 1,08 & 30,41 \\
\hline
\end{tabular}

Forrás: Saját szerkesztés, 2017

A kompetencia listát tartalmazó blokk hatfokozatú Likert-skálás értékeléseinek összegzése során megállapítható, hogy a rokonságba tartozó kompetenciák („Kommunikáció, tárgyalóképesség” és a „Jó beszédkészség”) közel azonos átlagértéket kaptak $(5,48$ és 5,46$)$. Az ezekhez tartozó szórás értékek sem mutatnak nagy különbséget $(0,72$ és 0,70$)$, itt a leghomogénebbek a hallgatók válaszai a listában. A szóbeli kifejezési készségeknek tulajdonított jelentőség származhat a karriercélok világos megfogalmazhatóságából, illetve a munkaerőpiac által támasztott követelményekből, ugyanis az álláskeresés folyamán meg kell tudni fogalmazni világosan a célokat és az elvárásokat. 


\section{TEMATIKUS TANULMÁNYOK - A munkaerőpiac gazdasági-társadalmi kérdései}

Viszonylag magas átlagértéket mutat továbbá a „Belső motiváció” $(5,33)$ is, amely értékelésénél a relatív szórás értéke $(15,40 \%)$ közepesen változékony. Kiemelendő elem továbbá az „Etikus hozzáállás” (átlagértéke: 4,20), melynél a relatív szórás értéke alapján $(26,64 \%)$ a válaszok erősen változékonyak. Ebbe a kategóriába sorolható még a „Kritikus szemléletmód” nevű kompetencia is a 28,71\%-os relatív szórásra kapott értékével. A kompetencialista legalacsonyabb átlagértékét a „Bizonytalanság toleranciája" kapta, ám itt az átlag nem alkalmas a sokaság egészének jellemzésére, mert a relatív szórás értéke (30,41\%) szélsőségesen ingadozónak tekinthető. Ez adódhat a munkatapasztalatok hiányából, tekintve a minta hallgatói összetételét.

Az állítások közti korrelációs kapcsolatok a 3. táblázatban kerülnek bemutatásra és értékelésre. A feltüntetett korrelációs kapcsolatok közepes korrelációt, jelentős kapcsolatot jeleznek.

3. táblázat. Korreláció a kompetenciák között

\begin{tabular}{|l|l|c|c|l|}
\hline \multicolumn{1}{|c|}{ 1. állítás } & \multicolumn{1}{|c|}{ 2. állítás } & $\begin{array}{c}\text { Szignifikan- } \\
\text { cia szint* }\end{array}$ & $\begin{array}{c}\text { Korrelációs } \\
\text { együttható }\end{array}$ & \multicolumn{1}{c|}{ Értékelés } \\
\hline $\begin{array}{l}\text { Jó beszéd- } \\
\text { készség }\end{array}$ & $\begin{array}{l}\text { Kommunikáció, } \\
\text { tárgyalókészség }\end{array}$ & 0 & 0,565 & $\begin{array}{l}\text { A jó beszédkészség a haté- } \\
\text { kony kommunikáció egyik } \\
\text { alapfeltétele. }\end{array}$ \\
\hline $\begin{array}{l}\text { Hibából való } \\
\text { tanulás }\end{array}$ & $\begin{array}{l}\text { Tanulás és telje- } \\
\text { sítmény fejlesz- } \\
\text { tése }\end{array}$ & 0 & 0,445 & $\begin{array}{l}\text { A hibából való tanulás } \\
\text { egyik módszere lehet az } \\
\text { onfejlesztés. }\end{array}$ \\
\hline $\begin{array}{l}\text { Felelősség- } \\
\text { tudat }\end{array}$ & $\begin{array}{l}\text { Hibából való } \\
\text { tanulás }\end{array}$ & 0 & 0,413 & $\begin{array}{l}\text { A hallgatók szerint a } \\
\text { hibából való tanulást } \\
\text { előremozdítja a felelősség } \\
\text { érzet megléte. }\end{array}$ \\
\hline $\begin{array}{l}\text { Jó beszéd- } \\
\text { készség }\end{array}$ & $\begin{array}{l}\text { Szokatlan helyzet- } \\
\text { és feladatmeg- } \\
\text { oldás }\end{array}$ & 0 & 0,401 & $\begin{array}{l}\text { A jó beszédkészség elő- } \\
\text { segíti a szokatlan helyze- } \\
\text { tek megoldását. }\end{array}$ \\
\hline
\end{tabular}

*A korrelációs együtthatók $\mathrm{p}<0,01$ szinten szignifikánsak.

Forrás: Saját szerkesztés, 2017

A 3. táblázat alapján látható, hogy a feltüntetett legerősebb korrelációs kapcsolat a kommunikációt érintő kompetenciáknál található. Ezt is alátámasztja a két kompetenciára kapott relatív szórásérték homogenitása. A fejlesztés és a hibából való tanulás is kapcsolatot mutat, ami az önfejlesztés hangsúlyba kerülésével áll összhangban. A hibák általi fejlődés segíthet a felelősségtudat kialakulásában. A jó beszédkészség megléte és a szokatlan helyzetekben való helytállás a kihívást jelentő esetekben ki- 


\section{TEMATIKUS TANULMÁNYOK - A munkaerőpiac gazdasági-társadalmi kérdései}

emelkedő jelentőséggel bír, mely a munkavégzés elkezdésénél, illetve a szakmai gyakorlatok teljesítésénél is előnyös.

A nemek bontásában vizsgálva szignifikáns eltérés figyelhető meg a felelősségtudat kérdésében $(p<0,05$; Khi-négyzet =9,636). A női válaszadók számára inkább fontos a „Felelősségtudat”, mint a férfiak számára, azonban a kapcsolat erőssége a Cramer-féle asszociációs együttható alapján gyenge $(0,190)$. Az „Etikus hozzáállás” kérdésében is hasonló különbség mutatható ki a nemek között ( $\mathrm{p}<0,05$; Khi-négyzet = 14,715; Cramer-féle asszociációs együttható =0,235).

Kor alapján nem sikerült differenciálni a válaszadókat. Ennek oka lehet, hogy a 18-21 és a 22-25 évesek is közel ugyanazt a generációt alkotják.

A lakóhely szerinti Khi-négyzet próbák nem mutattak ki eltérést a hallgatók preferenciái között. Nagyrészük az Észak-Alföldi régióban lakik, tehát gazdasági és társadalmi helyzetük nem sok esetben tér el drasztikusan az átlagtól, régiós sajátosságok jellemzik őket.

Szak szerinti vizsgálatnál a Kereskedelem-marketing szakos hallgatók statisztikailag kimutatható mértékben $(\mathrm{p}<0,05$; Khi-négyzet $=0,409)$ gondolták fontosnak a „Jó beszédkészség” meglétét. A terület sajátossága a megfelelő kifejezőkészség megléte, ami kifejezetten lényeges a végzettséggel való sikeres elhelyezkedés tekintetében. Közepesen jelentős a kapcsolat az állítás és a szak között, amelyet a Cramer-féle asszociációs együttható 0,409-es értéke támaszt alá. A képzési szint esetén nem sikerült differenciálni a kitöltőket.

\subsection{A SZOLGÁLTATÁSOK LEÍRÓ STATISZTIKÁJA, KORRELÁCIÓ ÉS KHI-NÉGYZET PRÓBÁK}

A szolgáltatások között szerepel az önismeret fejlesztése, az önéletrajz, motivációs levél írásában nyújtott segítség, telefonos, ill. személyes állásinterjúra való felkészítés, különböző álláskeresési technikák ismerete, tanulást segítő tréninek, valamint pályaorientációs tanácsadás is. Az értékelhető 11 szolgáltatás közül mindegyik közepesen erős vagy erős átlagértéket kapott $(4,4-5,4)$ és közepesen változékony ( 20\%) a relatív szórás értékük. A blokk elemei közül a legkevésbé lényegesre a „Telefonos állásinterjúra történő felkészítés” fontosságát (4,38 pont) értékelték a hallgatók. Ezzel szemben a tartomány felső részébe helyezték el $(5,31$ pont) a „Személyes állásinterjúra történő felkészítés" fontosságát. Leginkább olyan szolgáltatást vennének igénybe a megkérdezettek (5,36 pont), amely az „Aktív nyelvhasználatot támogatná”. Az egyik leghomogénebb (16,48\% relatív szórás) válaszadás jellemzi az állítást.

Az állítások közti legfontosabb korrelációs kapcsolat a 4. táblázatban kerül bemutatásra és értékelésre. A feltüntetett korrelációs összefüggés magas korrelációt, markáns kapcsolatot mutat. 
www. metszetek.unideb.hu

\section{TEMATIKUS TANULMÁNYOK - A munkaerőpiac gazdasági-társadalmi kérdései}

4. táblázat. Korreláció a szolgáltatások között

\begin{tabular}{|l|c|c|c|c|}
\hline \multicolumn{1}{|c|}{ 1. állítás } & 2. állítás & $\begin{array}{c}\text { Szignifikancia } \\
\text { szint* }\end{array}$ & $\begin{array}{c}\text { Korrelációs } \\
\text { együttható }\end{array}$ & Értékelés \\
\hline $\begin{array}{l}\text { Jó önéletrajz } \\
\text { megírása }\end{array}$ & $\begin{array}{l}\text { Jó motivációs } \\
\text { levél megírása }\end{array}$ & 0 & 0,889 & $\begin{array}{l}\text { A jó önéletrajz és moti- } \\
\text { vációs levél alapfeltétele } \\
\text { egy állásinterjúra törté- } \\
\text { nő eljutásnak. }\end{array}$ \\
\hline
\end{tabular}

* A korrelációs együttható $\mathrm{p}<0,01$ szinten szignifikáns.

Forrás: Saját szerkesztés, 2017

A nemek szerinti vizsgálat szignifikáns szinten $(\mathrm{p}<0,05)$ kimutatta, hogy a "Jó önéletrajz” és „Jó motivációs levél megírása” illetve a „Telefonos állásinterjúra való felkészülés” vagy „Személyes állásinterjúra történő felkészülés” (Khi négyzet =13,849-15,726; Cramer-féle asszociációs együttható =0,228-0,243) fontossága a női válaszadók számára fontosabb, mint az ellenkező nemé. A mindkét nem által leginkább igényelt szolgáltatás a „Tanulást segítő tréning” ( $\mathrm{p}=0,996$; Khi-négyzet $=0,369$ ). Ehhez kapcsolódó foglalkozást szervez a Debreceni Egyetem Hallgatói Karrierközpontja is a tanulási technikák elsajátításának megkönnyítéséhez.

Korok vagy lakóhelyek szerinti differenciáltság ebben az esetben sem valósult meg.

A szakok szerinti értékelés jelentős eltérést mutatott ki $(\mathrm{p}<0,05$; Khi-négyzet $=45,796$; Cramer-féle asszociációs együttható =0,422). A Gazdálkodás és menedzsment szakon tanuló hallgatók kevésbé igényelnének „Aktív nyelvhasználatot támogató szolgáltatás”-t, mint a Turizmus és vendéglátást vagy a Nemzetközi gazdálkodást hallgató társaik. Ez fakadhat a szakok és kimeneti követelményeik specifikusságából, ugyanis az utóbbi két szaknál elvárás a végzésig a két középfokú nyelvvizsga megszerzése.

\section{4. Összegzés}

A kutatás célja alapvetően a Debreceni Egyetem Gazdaságtudományi Karán lévő hallgatók véleményének felmérése volt a karrierjük előremozdítását szolgáló kompetenciák körében, valamint az eredményes álláskeresésben, elhelyezkedésben, pályaorientációban segítő szolgáltatásokra való igények tekintetében. A téma aktualitását igazolja, hogy napjainkban egyre több hangsúlyt helyezünk a kompetenciáink, képességeink fejlesztésére, hiszen a munkáltatók is nagy hangsúlyt tulajdonítanak a személyiségünknek, képességeinknek az állások betöltése során. Ha valaki el tudja dönteni, mely kompetenciák megléte szükséges a választott pályán, könnyebben tudja sajátjait felmérni, fejleszteni. 


\section{TEMATIKUS TANULMÁNYOK - A munkaerőpiac gazdasági-társadalmi kérdései}

A kérdőív eredményei alapján, a hallgatók nagy jelentőséget tulajdonítanak a kommunikációs képességeknek. A kompetenciák vizsgálata során korrelációs kapcsolat volt a „Hibából való tanulás” és a „Tanulás és teljesítmény fejlesztése” állítások között. A hallgatók nagy valószínűséggel vennék igénybe a személyes állásinterjúra való felkészülést segítő szolgáltatásokat, valamint az önéletrajz megírásával kapcsolatban is lényegesnek gondolják a segítséget, mint az egyetem által nyújtott szolgáltatást. A szolgáltatásokra elvégzett Khi-négyzet próba szerint, a kitöltők közül a nők számára fontosabb a jó önéletrajz, illetve motivációs levél megírása és az interjúra való felkészülés, mint a férfiaknak. Az eredményekhez igazodva megállapítható, hogy a hallgatók igényt tartanak az álláskereséshez, fejlődéshez segítséget nyújtó szolgáltatásokra. Javaslatként megfogalmazva, érdemes lenne a Karrierközpont szolgáltatásain kívül, minden egyetemi karon, szabadon választható tárgyként meghirdetni kompetenciafejlesztő tárgyakat, tanulás technikai tréningeket. A végzős évfolyamok esetén pedig hangsúlyt fektetni mind a telefonos, mind a személyes állásinterjúra való felkészítésre ugyancsak szabadon választható tárgyak keretében. Az egyetemi diploma megszerzése ebben az esetben párosulna azonnal felhasználható, hasznosuló munkaerőpiaci igényeknek megfelelő gyakorlati készségekkel is, ami különösen fontos a napjainkban jelentkező elhelyezkedési problémák megkönnyítésében.

\section{Irodalom}

Armstrong, M. (2012): Armstrong's Handbook of Human Resource Management Practice. Great Britain, Cambridge University Press.

Csehné Papp, I. (2016): Elvárások és realitások a munka világában. Taylor. VIII. évf. 2. sz., 5-10.

F. Silye, M. (2004): A szaknyelvoktatás és a szaknyelvi tudást felhasználók igényeinek elemzése és megjelenése egy angol szaknyelvoktatási programmodellben. Doktori disszertáció. Neveléstudományi Doktori Iskola. Eötvös Loránd Tudományegyetem.

Gaál, R. - Dióssi, E. - Benedek, Sz. (2013): Mindenki a kompetenciáról beszél! Munkaügyi Szemle 2013/III. sz., 32-40.

Henczi, L. - Zöllei, K. (2007): Kompetenciamenedzsment. Perfekt Gazdasági Tanácsadó, Oktató és Kiadó Zártkörűen Működő Részvénytársaság. Budapest.

Juhász, Cs. - Terjék, L. (2014): Elvárások vizsgálata az Y generációnál. Virtuális Intézet Közép-Európa Kutatására Közleményei. VI/2. (25), 221-226.

Koncz, K. (2013): Karriermenedzsment. Budapesti Corvinus Egyetem, Budapest. Nemeskéri, Gy. - Pataki, Cs. (2007): A HR gyakorlata. Ergofit Kft., Budapest. 
www. metszetek.unideb.hu

\section{TEMATIKUS TANULMÁNYOK - A munkaerőpiac gazdasági-társadalmi kérdései}

Nemeskéri, Gy. (2008): A HR tevékenységének differenciált megközelítése. Munkaügyi Szemle. 2008/1. Budapest, 67-73.

Powell, C. R. (1995): Career planning today: hire me. Kendall Hunt Publishing Company.

Takács, S. - Németh, M. - Juhászné Klér, A. - Toarniczky, A. (2017): Az egyetem melletti munkavégzés segítő és gátló tényezői diákszemmel. Vezetéstudomány XLVIII. évf. 3. sz., 39-55.

Spencer, L. M. - Spencer, S. M. (1996): Jéghegy modell, In: Mohácsi G.: Kompetencia-modell nemzetközi környezetben 1-2. rész. Humánpolitikai Szemle 1996/11-12. szám, 3-11. és 3-15.

Veresné Somosi, M. (2011): Alapvető képesség: a szervezeti és egyéni képesség fejlesztése. Magyar Minőség, 2010-2011/5., 11-20.

Watts, A. G. (2006): Career development learning and employability. Learning and Employability Series Two, The Higher Education Academy. https://aces.shu. ac.uk/support/staff/employability/resources/id592_career_development_learning_and_employability.pdf. Letöltés dátuma: 2018.02.03. 